\title{
PENGARUH BIMBINGAN BELAJAR ORANG TUA TERHADAP HASIL BELAJAR IPA SISWA KELAS IV SDN SEKECAMATAN PURING TAHUN AJARAN 2020/2021
}

\author{
Diah Palupi ${ }^{1}$, Ngatman $^{2}$, Tri Saptuti Susiani ${ }^{3}$ \\ Universitas Sebelas Maret \\ diahpalupi@student.uns.ac.id
}

\section{Article History}

accepted 1/11/2021

approved $1 / 12 / 2021$

published 31/12/2021

\begin{abstract}
This study aims to: 1) find out whether there is a positive influence of parental tutoring on the science learning outcomes of fourth grade elementary school students in Puring Sub-district in the academic year of 2020/2021, 2) find out the contribution of parental tutoring on the science learning outcomes of fourth grade elementary school students in Puring Sub-district in the academic year of 2020/2021. This research belongs to quantitative research using simple linear regression method. The population of this research is all fourth grade students of the elementary school in Puring Sub-district in the academic year of 2020/2021, consisting of 875 students. The sample of this study amounted to 293 fourth grade elementary school students in twelve public elementary schools throughout Puring Sub-district in the academic year of 2020/2021 who were randomly selected with probability sampling technique. The researcher uses questionnaires and learning outcomes tests to collect the data. The results showed that: (1) there was a positive and significant effect of parental tutoring on the science learning outcomes of fourth grade elementary school students in Puring Sub-district in the academic year of 2020/2021 with a regression of 0.255 and $r$ value $=0,505>r$ table $=0,325$. (2) The contribution of parental tutoring to the science learning outcomes of fourth grade elementary school students in Puring Sub-district in the academic year of 2020/2021 is 25.5\% and the remaining $74.5 \%$ is influenced by other factors such as interests, talents, intelligence, study habits, perseverance, family environment, school, community environment, etc.lt concludes that there is positive effect between parents-tutoring on natural science learning outcomes to fourth grade students of public elementary schools in Puring Sub-district in academic year of $2020 / 2021$ and the regression was 0.255 . The parents-tutoring contributes $25.5 \%$ on the natural science learning outcomes.
\end{abstract}

Keywords: Learning Outcomes, Parental Tutoring, Science

\begin{abstract}
Abstrak
Penelitian ini bertujuan untuk: (1) mengetahui adanya pengaruh positif bimbingan belajar orang tua terhadap hasil belajar IPA siswa kelas IV SDN se-Kecamatan Puring tahun ajaran 2020/2021; (2) mengetahui besarnya sumbangan bimbingan belajar orang tua terhadap hasil belajar IPA siswa kelas IV SDN se-Kecamatan Puring tahun ajaran 2020/2021. Penelitian ini merupakan penelitian kuantitatif dengan metode regresi linier sederhana. Populasi penelitian ini adalah seluruh siswa kelas IV SDN se-Kecamatan Puring tahun ajaran 2020/2021 yang berjumlah 875 siswa. Sampel pada penelitian ini berjumlah 293 siswa kelas IV SD di dua belas SDN se-Kecamatan Puring tahun ajaran 2020/2021 yang dipilih secara acak dengan teknik probability sampling. Teknik pengumpulan data menggunakan angket dan tes hasil belajar. Hasil penelitian menunjukkan bahwa: (1) terdapat pengaruh positif dan signifikan bimbingan belajar orang tua terhadap hasil belajar IPA siswa kelas IV SDN se-Kecamatan Puring tahun ajaran 2020/2021 dengan regresi sebesar 0,255 dan nilai $r$ hitung $=0,505>r$ tabel $=0,325$. (2) sumbangan bimbingan belajar orang tua terhadap hasil belajar IPA siswa kelas IV SDN seKecamatan Puring tahun ajaran 2020/2021 sebesar 25,5\% dan sisanya 74,5\% dipengaruhi oleh faktor lain seperti minat, bakat, kecerdasan, kebiasaan belajar, ketekunan, lingkungan keluarga,
\end{abstract}


sekolah, lingkungan masyarakat, dan lain sebagainya. Berdasarkan hasil penelitian tersebut, dapat disimpulkan bahwa terdapat pengaruh positif bimbingan belajar orang tua terhadap hasil belajar IPA siswa kelas IV SDN se-Kecamatan Puring tahun ajaran 2020/2021 dengan sumbangan bimbingan belajar orang tua terhadap hasil belajar IPA sebesar $25,5 \%$.

Kata Kunci: Bimbingan Belajar Orang Tua, Hasil Belajar, IPA

\section{PENDAHULUAN}

Anak dalam kehidupannya mengenal dan mengalami tiga lingkungan pendidikan. Ketiga lingkungan pendidikan tersebut adalah lingkungan keluarga, sekolah, dan masyarakat. Dari lingkungan pendidikan anak akan senantiasa belajar banyak hal, mulai dari hal yang kecil sampai hal yang besar. Dari belajar yang hanya untuk kepentingan dirinya sendiri sampai untuk orang lain bahkan masyarakat. Masingmasing lingkungan pendidikan mempunyai peran yang berbeda dan akan berpengaruh terhadap tumbuh kembang anak.

Lingkungan keluarga merupakan pusat pendidikan yang pertama dan utama bagi anak. Dari keluargalah anak mendapatkan pendidikan dan kasih sayang yang dibutuhkan oleh anak untuk bekal di kehidupannya. Dalam keluarga, ada sosok orang tua yang berperan dan berjasa dalam perkembangan anak. Orang tua juga berperan penting dalam memberikan bimbingan belajar kepada anak-anaknya. Menurut Hamalik (2010: 192) kebutuhan akan bimbingan belajar bagi para siswa disebabkan oleh perkembangan kebudayaan yang pesat memengaruhi perkembangan masyarakat keseluruhan. Dengan adanya bimbingan belajar, proses pembelajaran siswa di sekolah dapat berjalan dengan baik.

Bimbingan belajar merupakan usaha untuk mengatasi kesulitan-kesulitan belajar yang dialami oleh siswa. Hal ini tidak dapat dilepaskan dari karakteristik siswa dan permasalahan-permasalahan belajar yang selalu ada. Artinya, proses belajar dapat berjalan tanpa proses bimbingan, namun dengan adanya bimbingan belajar maka aktivitas belajar memiliki kemungkinan lebih besar untuk berhasil sehingga bimbingan belajar wajib diberikan kepada seluruh siswa dalam upaya mencapai keberhasilan belajar secara optimal. Untuk mengembangkan potensi dan kemampuan yang dimiliki siswa dibutuhkan bimbingan belajar dari orang tua. Bimbingan belajar sebaiknya diberikan oleh orang tua sejak dini, sebab membudayakan belajar kepada anak tidak bisa dilakukan dalam waktu singkat tetapi memerlukan proses yang panjang. Usaha itu dilakukan mulai dari bimbingan belajar dalam keluarga oleh orang tua.

Salah satu muatan pelajaran yang wajib ada di jenjang pendidikan dasar dan menengah yaitu IImu Pengetahuan Alam (IPA). IImu Pengetahuan Alam (IPA) dapat didefinisikan sebagai suatu kumpulan pengetahuan yang tersusun secara sistematik, dirumuskan secara umum, ditandai oleh penggunaan metode ilmiah, dan munculnya sikap ilmiah (Mariana dan Praginda, 2009: 23). Sejalan dengan Mariana dan Praginda, Fakhrudin, dkk. (2019: 1) menyatakan bahwa "Natural science (IPA) is collection of knowledge that is arranged systematically about natural indication" yang artinya IPA merupakan kumpulan ilmu pengetahuan yang tersusun secara sistematis tentang indikasi alam. Pembelajaran IPA di sekolah dasar dilakukan dengan penyelidikan sederhana dan bukan hafalan terhadap kumpulan konsep IPA, sehingga siswa mendapat pengalaman langsung melalui pengamatan, diskusi, dan penyelidikan sederhana. Pembelajaran yang demikian dapat menumbuhkan sikap ilmiah siswa, seperti: sikap ingin tahu, jujur, percaya diri, objektif, dan tidak tergesa-gesa.

Keberhasilan pendidikan dapat dilihat dari nilai hasil belajar yang diperoleh siswa. Semakin tinggi nilai hasil belajar yang dimiliki siswa, maka akan semakin baik pula keberhasilan pendidikan yang dilakukan. Sudjana (2013: 22) mengemukakan bahwa hasil belajar adalah suatu keahlian yang diperoleh siswa setelah memperoleh pengalaman belajar. Hasil belajar tersebut dapat digunakan sebagai tolak ukur untuk 
mengetahui seberapa jauh siswa menguasai kompetensi yang telah diajarkan. Tercapainya keberhasilan dalam belajar tentunya dipengaruhi beberapa faktor. Sobur (2016: 212) menyatakan bahwa faktor-faktor yang memengaruhi hasil belajar siswa dibagi menjadi dua bagian yaitu faktor endogen dan eksogen. Faktor endogen (faktor internal), yaitu semua faktor yang berada di dalam diri individu. Faktor ini terdiri dari faktor fisik dan psikis. Faktor fisik misalnya kesehatan dan cacat tubuh. Faktor psikis misalnya intelegensi atau kemampuan, perhatian dan minat, bakat, motivasi, kematangan, dan kepribadian. Sedangkan faktor eksogen (faktor eksternal), yaitu semua faktor yang berada di luar diri individu. Faktor ini meliputi faktor keluarga, sekolah, dan lingkungan lain.

Keluarga merupakan faktor eksternal yang memengaruhi hasil belajar siswa. Melalui wawancara di SD Negeri 2 Sidoharjo pada hari Sabtu, 7 November 2020 diperoleh informasi mengenai hasil belajar IPA siswa kelas IV SD. Guru kelas IV SD menyampaikan bahwa nilai yang diperoleh siswa sangat beragam, terdapat siswa yang mendapat nilai rendah, sedang, dan tinggi. Menurut hasil wawancara dengan beliau Ibu Istiroah selaku guru kelas IV SD Negeri 2 Sidoharjo, nilai muatan pelajaran IPA siswa kelas IV SD masih terbilang rendah. Hal ini dikarenakan kurang optimalnya bimbingan belajar orang tua terhadap anak, minimnya pengetahuan orang tua maupun siswa dalam mengikuti pembelajaran, dan adanya kesibukan orang tua. Hal ini diperkuat dengan pernyataan beberapa orang tua siswa yang mengungkapkan bahwa sebagian besar waktu mereka dihabiskan untuk bekerja di luar rumah, sehingga waktu untuk membimbing belajar anak tidak maksimal. Bahkan, beberapa orang tua yang bekerja di luar kota menitipkan anaknya kepada saudara atau kakek dan neneknya, sehingga anak kurang mendapatkan bimbingan belajar orang tua. Alhasil, hasil belajar siswa tidak maksimal (rendah).

Berdasarkan paparan di atas, peneliti tertarik untuk mengetahui adanya pengaruh positif bimbingan belajar orang tua terhadap hasil belajar IPA siswa kelas IV SDN se-Kecamatan Puring tahun ajaran 2020/2021 dan mengetahui besarnya sumbangan bimbingan belajar orang tua terhadap hasil belajar IPA siswa kelas IV SDN se-Kecamatan Puring tahun ajaran 2020/2021 melalui penelitian kuantitatif dengan judul "Pengaruh Bimbingan Belajar Orang Tua Terhadap Hasil Belajar IPA Siswa Kelas IV SDN Se-Kecamatan Puring Tahun Ajaran 2020/2021".

\section{METODE}

Penelitian ini menggunakan desain penelitian kuantitatif dengan metode regresi. Populasi penelitian ini adalah seluruh siswa kelas IV SD di 38 SDN se-Kecamatan Puring tahun ajaran 202/2021 yang berjumlah 875 siswa. Sampel penelitian ini berjumlah 293 siswa kelas IV SD di dua belas SDN se-Kecamatan Puring yang dipilih secara acak dengan teknik probability sampling, yaitu teknik pengambilan sampel dengan memberikan peluang yang sama bagi setiap anggota dalam populasi untuk dipilih menjadi anggota sampel (Sugiyono, 2013: 120). SD yang digunakan dalam penelitian ini yaitu SDN 1 Purwosari, SDN 1 Sidobunder, SDN 1 Sidoharjo, SDN 1 Surorejan, SDN 2 Banjarejo, SDN 2 Bumirejo, SDN 2 Kedaleman Wetan, SDN 2 Puliharjo, SDN 2 Sidobunder, SDN 2 Sidoharjo, SDN 3 Tambakmulyo, dan SDN Kedaleman Kulon.

Teknik pengumpulan data yang digunakan dalam penelitian ini yaitu menggunakan angket dan tes. Angket digunakan untuk mengumpulkan data bimbingan belajar orang tua dan tes digunakan untuk mengumpulkan data hasil belajar IPA siswa kelas IV SD. Uji prasyarat data yang digunakan pada penelitian ini yaitu uji normalitas dan uji linieritas. Analisis data yang digunakan pada penelitian ini yaitu regresi linier sederhana dan sumbungan efektif (SE).

HASIL DAN PEMBAHASAN 
Penelitian ini dilakukan dengan memberikan angket bimbingan belajar orang tua dan tes hasil belajar IPA kepada siswa di dua belas SDN di Kecamatan Puring tahun ajaran 2020/2021. Angket berisi mengenai indikator-indikator yang berhubungan dengan bimbingan belajar orang tua sehingga dapat mengukur tinggi rendahnya bimbingan belajar orang tua terhadap siswa khususnya dalam hal belajar. Tes hasil belajar berisi soal-soal yang memuat materi IPA kelas IV SD sehingga dapat mengukur tinggi rendahnya hasil belajar IPA kelas IV SD. Uji prasyarat data penelitian ini terpenuhi yaitu data berdistribusi normal dan terdapat hubungan linier bimbingan belajar orang tua terhadap hasil belajar IPA siswa kelas IV SD. Data hasil penelitian ini berasal dari data berdistribusi normal yang ditunjukkan dengan nilai signifikansi bimbingan belajar orang tua sebesar 0,200 dan nilai signifikansi hasil belajar IPA sebesar 0,096 . Kedua nilai signifikansi tersebut menunjukkan nilai $>0,05$ sehingga data tersebut berasal dari populasi berdistribusi normal. Data hasil penelitian ini juga terdapat hubungan linier antara bimbingan belajar orang tua dan hasil belajar IPA kelas IV SD yang ditunjukkan dengan nilai $\mathrm{p}$ value Deviation from Linearity yaitu sebesar $0,351>0,05$, karena jika $p$ value Deviation form Linierity menunjukkan nilai $>0,05$ dapat dikatakan data tersebut terdapat hubungan linier antara variabel $\mathrm{x}$ dan $\mathrm{y}$.

Pengaruh bimbingan belajar orang tua terhadap hasil belajar IPA siswa kelas IV SD diuji menggunakan uji regresi linier sederhana dengan bantuan aplikasi Statistical Product and Service Solutions (SPSS) versi 21. Hipotesis yang digunakan yaitu $\mathrm{Ho}=$ tidak terdapat pengaruh positif bimbingan belajar orang tua terhadap hasil belajar IPA siswa kelas IV SDN se-Kecamatan Puring tahun ajaran 2020/2021 dan $\mathrm{Ha}=$ terdapat pengaruh positif bimbingan belajar orang tua terhadap hasil belajar IPA siswa kelas IV SDN se-Kecamatan Puring tahun ajaran 2020/2021.

Tabel 1.1 Data Bimbingan Belajar Orang Tua dan Hasil Belajar IPA

\begin{tabular}{ccccc}
\hline \multirow{2}{*}{ No } & \multicolumn{2}{c}{ Bimbingan Belajar Orang Tua } & \multicolumn{2}{c}{ Hasil Belajar IPA } \\
\cline { 2 - 5 } & Interval & Frekuensi & Interval & Frekuensi \\
\hline 1. & $56-60$ & 7 & $13-22$ & 7 \\
\hline 2. & $61-65$ & 24 & $23-32$ & 23 \\
\hline 3. & $66-70$ & 26 & $33-42$ & 24 \\
\hline 4. & $71-75$ & 67 & $43-52$ & 44 \\
\hline 5. & $76-80$ & 70 & $53-62$ & 57 \\
\hline 6. & $81-85$ & 51 & $63-72$ & 63 \\
\hline 7. & $86-90$ & 33 & $73-82$ & 38 \\
\hline 8. & $91-95$ & 11 & $83-92$ & 24 \\
\hline 9. & $96-100$ & 4 & $93-100$ & 13 \\
\hline \multicolumn{5}{c}{ Total } \\
\hline
\end{tabular}

Tabel 1.2 Hasil Analisis Regresi Bimbingan Belajar Orang Tua Terhadap Hasil Belajar IPA Siswa Kelas IV SD

Model Summary

\begin{tabular}{lrrrr}
\hline Model & $R$ & $R$ Square & Adjusted R Square & $\begin{array}{c}\text { Std. Error of the } \\
\text { Estimate }\end{array}$ \\
\hline 1 & $.505^{\mathrm{a}}$ & .255 & .253 & 16.521 \\
\hline
\end{tabular}

a. Predictors: (Constant), Bimbingan Belajar Orang Tua

Berdasarkan analisis data tersebut, dapat diketahui bahwa besarnya nilai koefisien korelasi $(R)$ sebesar 0,505 dan koefisien determinasi ( $R$ Square) sebesar 0,255 dengan nilai $r$ hitung $=0,505>r$ tabel $=0,325$, artinya pengaruh bimbingan belajar orang tua terhadap hasil belajar IPA sebesar $25,5 \%$ dan $r$ hitung $>r$ tabel 
berarti terdapat pengaruh positif bimbingan belajar orang tua terhadap hasil belajar IPA siswa kelas IV SD. Oleh karena itu, semakin tinggi bimbingan belajar orang tua, maka semakin tinggi pula hasil belajar IPA siswa. Sebaliknya, semakin rendah bimbingan belajar orang tua, maka semakin rendah pula hasil belajar IPA siswa.

Hal ini diperkuat dengan penelitian yang dilakukan oleh Mulyaningsih (2016: 178) yang mengemukakan bahwa ada pengaruh yang positif dan signifikan antara bimbingan belajar orang tua dengan hasil belajar matematika siswa kelas V SD seGugus Diponegoro Kecamatan Bansari Kabupaten Temanggung dengan koefisien determinasi (R2) sebesar 0,279 atau $(27,9 \%)$. Artinya bimbingan belajar orang tua sebagai variebel independen memberikan sumbangan pengaruh terhadap hasil belajar matematika sebesar $27,9 \%$, pengaruh yang terjadi positif apabila semakin meningkatnya bimbingan belajar orang tua maka semakin meningkat pula hasil belajar matematika siswa. Sejalan dengan penelitian Puspoarum (2014: 10) bahwa bimbingan belajar orang tua mempunyai pengaruh yang signifikan secara parsial terhadap prestasi belajar siswa kelas III SDN 3 Winong dengan t hitung variabel bimbingan belajar orang tua sebesar $t$ hitung $(4,733)>t$ tabel $(2,110)$ pada taraf signifikan $5 \%$, sehingga dapat dinyatakan bahwa semakin baik bimbingan belajar orang tua terhadap siswa, maka semakin baik prestasi belajar siswa tersebut. Sebaliknya, jika bimbingan belajar orang tua semakin berkurang, maka prestasi belajar siswa akan semakin menurun.

Menurut Septiana (2016: 39) dalam aktivitas belajar, peranan orang tua dalam keluarga adalah memberikan bimbingan belajar, seperti: mengarahkan cara belajar yang baik, menentukan waktu belajar, membantu mengatasi kesulitan belajar, menyediakan fasilitas belajar, memberikan motivasi belajar, dan membentuk kebiasaan belajar. Cukup atau kurangnya bimbingan belajar orang tua dapat memengaruhi pencapaian hasil belajar siswa. Dengan adanya pemberian bimbingan belajar oleh orang tua kepada siswa secara maksimal, maka dapat meningkatkan motivasi belajar siswa, membantu siswa dalam mengatasi kesulitan belajar, memenuhi kebutuhan belajar, dan dapat meningkatkan hasil belajar siswa.

Hasil perhitungan sumbangan efektif bimbingan belajar orang tua terhadap hasil belajar IPA siswa kelas IV SDN se-Kecamatan Puring tahun ajaran 2020/2021 sebesar $25,5 \%$ dan sisanya $74,5 \%$ dipengaruhi oleh faktor lain, seperti: minat, bakat, kecerdasan, kebiasaan belajar, ketekunan, lingkungan keluarga, sekolah, lingkungan masyarakat, dan lain sebagainya.

\section{SIMPULAN}

Berdasarkan hasil penelitian pengaruh bimbingan belajar orang tua terhadap hasil belajar IPA siswa kelas IV SDN se-Kecamatan Puring tahun ajaran 2020/2021 dapat ditarik kesimpulan sebagai berikut: (1) bimbingan belajar orang tua berpengaruh positif terhadap hasil belajar IPA siswa kelas IV SDN se-Kecamatan Puring tahun ajaran 2020/2021 dengan regresi sebesar 0,255 dan nilai $\mathrm{r}$ hitung $=0,505>\mathrm{r}$ tabel $=$ 0,325 serta $\mathrm{t}$ hitung $=9,986>\mathrm{t}$ tabel $=1,968$. (2) Sumbangan efektif bimbingan belajar orang tua terhadap hasil belajar IPA siswa kelas IV SDN se-Kecamatan Puring tahun ajaran $2020 / 2021$ sebesar $25,5 \%$ dan sisanya $74,5 \%$ dipengaruhi oleh faktor lain, seperti: minat, bakat, kecerdasan, kebiasaan belajar, ketekunan, lingkungan keluarga, sekolah, lingkungan masyarakat, dan lain sebagainya.

\section{DAFTAR PUSTAKA}

Fakhrudin, A., Sri, Y., \& Riyadi, R. (2019). Implementation of Augmented Reality Technology in Natural Sciences Learning of Elementary School to Optimize The Students Learning Result. International Journal of Indonesian Education and Teaching (IJIET), 3(1), 1-10. 
Hamalik, O. (2010). Psikologi Belajar dan Mengajar. Bandung: Sinar Baru Algensindo.

Mariana, M. A. dan Praginda, W. (2009). Hakikat IPA dan Pendidikan IPA. Bandung: Pusat Pengembangan dan Pemberdayaan Pendidik dan Tenaga Kependidikan IImu Pengetahuan Alam (PPPPTK IPA).

Mulyaningsih. (2016). Pengaruh Bimbingan Belajar Orang Tua terhadap Perilaku Disiplin dan Hasil Belajar Matematika Siswa Kelas V SD Se-Gugus Diponegoro Bansari Temanggung. Skripsi Tidak Dipublikasikan. Semarang: FKIP Universitas Negeri Semarang.

Puspoarum, M. (2014). Pengaruh Bimbingan Belajar Orang Tua terhadap Prestasi Belajar Siswa Kelas III SDN 3 Winong Kecamatan Boyolali Kabupaten Boyolali Tahun Pelajaran 2013/2014. Skripsi Tidak Dipublikasikan. Surakarta: FKIP Universitas Muhammadiyah Surakarta.

Septiana, P. (2016). Hubungan Bimbingan Belajar Orang Tua dengan Hasil Belajar IPS Peserta Didik Kelas V SDN Gugus Erlangga Kecamatan Pecangaan Kabupaten Jepara. Skripsi Tidak Dipublikasikan. Semarang: FKIP Universitas Negeri Semarang.

Sobur, A. (2016). Psikologi Umum. Bandung: CV Pustaka Setia.

Sudjana, N. (2013). Penilaian Hasil Proses Belajar Mengajar. Bandung: PT Remaja Rosdakarya.

Sugiyono. (2013). Metode Penelitian Pendidikan-Pendekatan Kuantitatif, Kualitatif, dan $R \& D$. Bandung: Alfabeta. 